\title{
Globalization and Multinational Corporations: The Nigerian Business Environment in Perspective
}

\author{
Osibanjo, A. O.; Oyewunmi, A. E. \& Salau, O. P.
}

\begin{abstract}
The paper attempts an encompassing definition of the concept of globalization. It examines different but critical insights on the theme of economic globalization, as well as the view that multinational corporations are important conveyors of it. It also provides perspective on the varying challenges multinational corporations may contend with in Nigeria's evolving business environment.

Key words: Globalization, Multinational Corporations, Human Resources, Nigeria.
\end{abstract}

\section{Introduction: Defining Globalization}

Globalization is a myth (Wind, 1986; Eaton, 2000), it is an irresistible force (Giddens, 1999), it is a hideous word (Wolf, 2004), it is like the weather or gravity (Bisley, 2007). Over the years, academics and economists have waged raging battles of semantics in a bid to come to terms with what globalization is, what it is not, who it benefits and who it does not. It is a subject of growing controversy, and there seems to be no consensus on the idea.

The world is converging socially, politically and more importantly for the purpose of this discourse, economically. As a result, globalization can be defined socially, politically, and economically. Berger (2002) defines social globalization as 'an intensified continuation and an accelerated form of modernization, which on a cultural level has enhanced the breakdown of traditions and the opening up of multiple options for beliefs, values, and lifestyle'. Globalization is a social force (Parker, 1998), which according to Chilsom (1946), is instrumental in creating a world government where people's minds will be devoid of their 'individualism, loyalty to family traditions, national patriotism and religious dogmas, substituted by rational and intelligent thinking that will chart the change in human behaviour'.

Maddock (2002) frowns at this view, stating that social globalization by substituting individualism and family with interest groups, has managed to create discord among the elements of society and has also created class victims, i.e. workers, people of colour and women, thereby generating strains in the society. There have also been fears that social globalization is a threat to the loss of national culture as a result of the homogenization of lifestyles around the world (Hammond and Gross, 2003). The surge in social media in recent years has also facilitated social globalization. Social platforms like Twitter, Facebook, Instagram and many others have contributed greatly towards breaking territorial boundaries.

The policies (international and domestic alike) of government have driven the push towards globalization, hence emphasizing the unique importance of political globalization. For instance, the Nigerian effort to break down geographic and economic barriers through the facilitation of initiatives like the Economic Community of West African States (ECOWAS) free trade zone is a manifestation of this trend. Other examples can be seen in North American Free Trade Agreement (NAFTA) and Association of South-East Asian Nations (ASEAN). Brawley's (2003) definition aligns with this position when he states that political globalization is 'competing processes involving both territorial diffusion of things and people and ideas and the process through which different parts of the world gradually become inter-dependent'. He also refers to it as a state of mind about the world where individuals conceive their place in society in political global terms.

These definitions attest to the fact that the world is so to speak shrinking into a village; nations are becoming more inter-dependent and organizations like the European Union have sprung up where nation-state is no longer important (Maddock, 2002). World politics has become a complex stage with a vast array of nations interacting as actors with different interests, power capacities and the entire population of the world participating in a global system of political relations governed by accepted norms and rules (Bisley, 2007).

Dominating this contemporary global political system is the United States of America outstripping all others in all measures of military, political and economic influence (Brooks and Wohlforth, 2002). In this light, critics have sometimes substituted globalization with Americanization opining that globalization has increased the vulnerability of nations as targets at the mercy of world powers like America (Bisley, 2007). Wolf (2004) asserts that it is this fear of vulnerability that fueled the September 11 attack on the United States by those he describes as 'dangerous enemies of modernity who are full of hatred at the west's impact on their territories and values'.

Economic globalization which is the basis of this discourse has been variedly defined. The International Monetary Fund (2000) a significant factor in world economics and politics refers to economic 
globalization as the increasing integration of economies, through trade and financial flows as well as the movement of labour and technology across international borders. The former chief economist of the Organization for Economic Cooperation and Development, David Henderson (1999), defined globalization as 'a free movement of goods, services, labour and capital, thereby creating a single market inputs and outputs and full national treatment of foreign investors, so that economically speaking there are no foreigners'. Brawley (2003) also regards globalization as 'a process whereby markets and production in different countries become interdependent due to the dynamics of trade in goods and services and flow of capital, technology and labour'.

Certain subjects are germaine to the process of globalization; one of such subjects is the technological progress apparent in the evolution of the internet, which Frynas (2002) also refers to as the borderless cyberspace. Technological progress is also manifest in communication and transport sector as the world has moved from the era of telex, telegrams and surface mails to that of electronic mail, e-commerce and mobile phones. Other subjects are global market, which signifies the interaction of international countries via trade and offers the 'opportunity to tap into larger markets around the world' (IMF, 2000); the movement of goods which implies that a Chinese product or brand can be found on market shelves in United Kingdom; the movement of labour which refers to the migration of human resource around the world and the movement of capital which is a primal function of foreign direct investments.

These elements are the drivers of the globalization process, engineering the creation of a global village where world economies are interdependent and markets integrated (IMF, 2000). However, the consequence of this interdependence is that the economic success or failures of a nation or state may affect others positively or adversely (Wolf, 2004) and this is where the globalization debate stems from

\section{Review: The Globalization Debate}

There are diverse views on the concept of globalization. Amongst the divergence of interpretations one fact is constant; globalization is about the engagement, interaction or association of people beyond territorial barriers, at different levels and for different but specific purposes or reasons.

Commentators have echoed their support for or discontent with the concept of globalization. Wright (2000) states that, 'a common stereotype of globalization is that it is something done by the rich, for the rich and to the poor'. This view aptly captures the perspective of the opponents of economic globalization on what it is and what its consequences are. British journalist, Lloyd (2001) shares this perspective as he opines that 'globalization is Western capitalism... which is an oppressive and impoverishing force'. The view of opponents of economic globalization is that it is beneficial only to the powerful and developed countries of the world to the detriment of the developing countries with the exception of Asia which seems to be increasing in influence with the economic growth in China and India (Brisley, 2002). The unequal manifestation of the gains of economic globalization informs the view that the West benefits disproportionately thereby 'engendering economic losses, social dislocation and growing inequalities' (Khors, 2000; Jenkins, Lee and Rodgers, 2007).

The International Monetary Fund (IMF, 2000) disagrees with the stereotype by opponents of globalization, stating that it is wrong to conclude that globalization has caused the inequality between the rich and the power. Rather, it offers extensive opportunities for world development. The IMF attributes the inability of poorer countries to integrate into the global economy and reap its benefits, to their chosen policies and other factors outside their control. This implies that the policies of poorer nations may not encourage economic globalization. Socio-economic and political challenges are dominantly contributory factors as well. Wolf (2004), attests that richer countries have been able to harness the opportunities of globalization by investing in skill and this has led to a large supply of human skill raising capital and enhancing economic growth. Supporters of economic globalization believe that inequality between the rich and the poor is not caused by globalization but by the inability of poor countries to adapt to the change process and adopt policies that will make the change advantageous.

The IMF (2000) encourages 'international communities to help poor countries integrate into world economy, grow rapidly and reduce poverty by strengthening the international financial system through trade and aid'. Inadvertently, this seems to buttress Wright's (2000) view, as it depicts an imagery of the international community being the rich big brother lending a helping hand to the seemingly helpless poor countries.

A former president of the World Bank, Zoellick, in an edition of China's People Daily (2008), maintains the stance that globalization has immensely helped developing countries reduce poverty. Kruger (2002) and Aninat (2002) also agree that globalization has effectively aided the optimal allocation of world resources via free trade and has boosted incomes and raised the standard of living around the world. However, critics argue that economic globalization has led to unemployment around the world (Jenkins et al, 2007, Hammond and Gross, 2003) as multinational corporations in their activities, seek to optimize profit and pitch their tents where factors of production are cheap (Mendenhall, Punnet and Ricks, 1995). An example of this is the closure of the Burberry Factory in Rhondda Valley, South Wales, United Kingdom and movement of its 
operations to China, leading to three hundred and nine (309) individuals losing their source of livelihood (Cadwalladr, 2007).

Supporters of economic globalization have not failed to highlight the many technological conquests brought about by globalization (Mardsen, 2004). These conquests as earlier mentioned are evident in the advent of the internet for instance, which has acted as a catalyst in every sector of the economy. Opponents agree with this claim as Wright (2004) notes that there is improvement in the transport and processing of matter, improvement in the transport and processing of energy and improvement in the transport and processing of information'.

Wright (2004) is however quick to observe that, globalization is costly to the human race as a result of 'the growing access to catastrophic technologies like biological and nuclear weapons'. These nuclear weapons are possessed by world powers i.e. United States, United Kingdom, Russia, France and China. Weak states and societies become faced with an existential threat and this makes them vulnerable (Bisley, 2007).

According to Wolf (2004), many of the views held by the critics of globalization are baseless and wrong. He accuses them of 'disregard for facts and professional economic analyses' and refers to them as 'idealistic spoilt children'. He reviews some of the popular views of opponents and based on analysis, infers the following; global inequality has not risen but has fallen since the 1970s, the number of people in extreme poverty has not risen, but has fallen since 1980s due to the economic growth in Asia, the proportion of the world's population in extreme poverty has fallen, income has not risen in countries that have integrated in world economy

The effects of globalization in Nigeria have generated differing perspectives. According to Majekodunmi and Adejuwon (2012) there are many instances of the negative effects of globalization on the Nigerian economy in terms of inflation/devaluation of currency and the collapse of local industries like the textile and automobile sectors. Another instance stated is that globalization has created an avenue for corrupt government officials to loot public funds, as well as the fact that whilst Nigerian exports promote economic diversification abroad, it restricts diversification in the domestic setting. Obaseki (2000) argues that the positive effects of globalization in Nigeria include, international specialization, high quality but low cost products and free flow of investment capital.

The globalization debate is hugely confusing with its differing conceptions, ceaseless arguments and the inability of supporters and opponents to reach a consensus (Brinkman and Brinkman, 2002). Although there is a consensus on the complexity of the subject, it is doubtful that these arguments will cease

\section{Multinational Corporations: Conveyors of Economic Globalization}

The surge in the development of Multinational Corporations around the 1980s bears a definite link to the pervasiveness of economic globalization. In fact, modern day globalization is identified by the actions of multinationals. Their operations span across multiple countries, cultural styles and economic power from one country to another, acting as facilitators of economic globalization (Cook, 2006). Reich (1994) notes that; 'the increasing fleet footed-ness of businesses around the world via technological developments' has impacted greatly on global integration by making the process easier. It is also said that Foreign Direct Investment (FDI) which is an empirical feature of multinationals is growing faster than global trade (Brinkman and Brinkman, 2002). United Nations Conference on Trade and Development (UNCTAD) (2004) highlights a twelve (12) fold increase in FDI and an eight (8) fold increase in the number of multinationals, lending credence to the extraordinary growth in economic globalization.

A multinational corporation is defined as an enterprise 'that in more than one country owns or controls production or service facilities and activities that add value' (Leat, 2003). It is also one that is primarily located and managed from the country of its origin but produces goods or services in relatively autonomous overseas subsidiaries to meet the demands of local markets (Rollinson, 2005; Hill, 2005). The product or service can be required to satisfy not only local markets but also international markets, as brands of a certain country can be found in the markets of several other geographically distant countries through foreign direct investment or other channels of distribution.

In cases where products are meant for overseas market, overseas subsidiaries may require a higher level of operating autonomy to design, develop and market their own products (Beamish, Killing, LeCraw and Crockell, 1991). For instance, if Levis Jeans, an originally American brand, begins operations in Netherlands which is famously said to be inhabited by the world's tallest people; with the aim of supplying to that market, it has to take the needs of that particular market into careful consideration in its production. Another case in point could be Mobile Telecommunication Network (MTN), a South African brand, which in order to penetrate the Nigerian market, had to take due cognizance of the prevailing local factors of language, level of sophistication and culture.

The factors that propel the cross-national activities of multinational corporations include, access to resources, economic/ political factors and competitor activity (Gilpin, 1987; Ozoigbo and Chukuezi, 2011). The 
activities of multinationals in achieving the above objectives have come under the intense scrutiny of the transformative perspective (Parker, 1998). Sparrow (2004) assesses that multinationals unleash a social force which they themselves cannot handle. This implies that the activities of multinationals impacts on their environment and this has generated criticisms from different quarters. For instance, environmental criticisms (also called green agenda) emanates from unconstrained activity of multinationals resulting to or accelerating the depletion of resources such as forests and causing global warming (Wild, 2003).

Labour criticisms (blue agenda) are based on the dangers of exploitative child labour, human rights abuse, biased labour standards and all sorts of issues perceived to affect labour (Hepple, 2001). An instance of labour criticism that generated much controversy and almost damaged the reputation of the multinational in question was the discovery of ten (10) years old children making embroidery on GAP branded clothing in New Delhi, India. Not only were the children used unlawfully, they were not paid any wages (McDougall, 2007). Non-governmental organizations (and pressure group) like Amnesty International are focusing more attention on labour related issues as multinationals are increasing their spread day by day. These groups advocate against the exploitation of labour by multinationals and have the ability to damage the brand reputation of a multinational to the extent of affecting sales volume (Wild, 2003). This is why multinationals undertake various forms of corporate social responsibility (CSR) in the communities in which they exist, to endear pressure groups and the community at large to them and enhance their (Bulus and Ango, 2012).

\section{The Nigerian Business Environment in Perspective}

Modern organizations operate and compete in a volatile business environment given the spate of globalization, transforming technological advancements and several other factors. Organizations exist, co-exist, compete and cooperate in a dynamic and interrelated environment that is characterized by complexity. This implies that just like organisms, organizations have to adapt to the dynamic environment in which they exist (Morgan, 1996). Multinationals have to contend with certain primal issues when making entry into and maintaining relevance in any host country.

The Nigerian context can reasonably be described as an unfolding one, as the policies underpinning many key sectors are still maturing and evolving. It has also been labeled in different forums with regards to matters of; policy inconsistency, lack of transparency and accountability in relation to execution of specific political, social, financial and economic fundamentals. In these circumstances, multinationals usually bear the unenviable burden of making strategic business decisions on the basis of faulty assumptions which could impact negatively in the foreseeable future. In light of the peculiarities associated with the Nigerian business terrain; it is needful to expound specific issues that multinational organizations should prioritize in terms of the consequences it portends.

\section{Political Disposition:}

This phrase is also usually referred to as the 'political will' of a subsisting government to do, partly do or refrain from doing anything which from all reasonable estimation will result to the greatest benefit to the greatest number of persons. The question then is how to effectively measure or ascertain the level of political disposition attributable to a particular government or it agencies. A practical way to achieve this is by assessing the degree of commitment applied to a given cause of action. Once this attribute (commitment) begins to wane and eventually culminates in a distraction from identified goals, it may be practical in such circumstances, to conclude that political will is lacking within the system (that is, even if it existed in the first instance).

In specific terms, positive political disposition will suggest on the part of the prevailing government; ensuring compliance with the rule of law, preserving due processes, implementing international standards and best practices. An inclination towards such indices serves as the basis to forge an enabling environment for human participants within any given context. The absence of which is a dis-incentive to willing multinationals to establish businesses and when they actually do, it provides viable impediment to expansion possibilities in the future. In 2012, Richard Branson, the chairman of the Virgin Group shared his frustrations on doing business in Nigeria. as result of the poor political disposition. He stated the corruption inherent in the Nigerian government, the poor political disposition and bureaucratic structure of agencies.

Nigeria is usually considered as a country with manifold potentials and unrealized expectations. Actually, it is the failure to resolve certain fundamentals that has prevented human resource and expertise from making enduring contributions that would positively impact on the socio-economic fabric of the nation. In essence, once these underlying issues are appropriately managed, it should result in a transfer of the required confidence-levels to a variety of organizations to deposit the requisite skills-set and expertise in Nigeria over a sustained period. Thus, the more multinational corporations regard Nigeria as a place they can truly call a "home", the higher the chances of Nigeria achieving enduring economic prosperity. 


\section{Legal and Regulatory Climate:}

The nature of the legal and regulatory environment of a country represents one of the basic parameters to assess the posture of the government on central issues that affect the wellbeing of the citizenry. In specific terms, it alludes to the fact as to whether or not there is a viable platform for local and foreign businesses to build and grow their diverse commercial interests. The attainment of an effective legal and regulatory framework is very important for Nigeria because it will enable the benchmarking of its processes, labour and human resource management practices inclusive, against what is obtainable in other mature climes. This approach will also result in the adapting of existing models to suit prevailing local circumstances in Nigeria towards achieving practical goals of; enhancing local skill levels, developing mature labour laws and regulations, effective dispute resolution mechanisms and sustenance of functional regulatory agencies on matters of education, training, corporate social responsibility and local content.

Nigeria's legal environment is still relatively weak as there is no correlation between the number of available legal officers and regulatory agencies and the rate of compliance and enforcement. Also, the level of funding that is dedicated to these aspects of governance (legal and regulatory) is partly responsible for the declining performance of the relevant agencies in this respect. It is noteworthy, that the high incidence of agency duplication as opposed to the empowerment of functional agencies has blurred the essence of regulation of multinationals in several respects. As a consequence of Nigeria's inconsistent legal and regulatory environment, multinational corporations may have to contend with many uncertainties which may result in unintended consequences.

In Nigeria, it is not unusual for foreign businesses to assign expatriates to fill positions within their organizations inspite of available local options. The weak regulatory regime permits the uncontrolled influx of foreigners into Nigeria with limited consideration as to the impact on the local employment conditions, bearing in mind the prevailing high rate of unemployment. Also, as a result of the pressure to attract new businesses and encourage economic growth, there is an apparent urge to ease the requirements on expatriate quotas. Hence, the need to maintain an effective balance as regards the training and placement of local manpower is progressively eroded. As the emphasis on the enhancement of local skills degenerates, the same multinationals that are being canvassed, may in time label this trend as an added disincentive not to establish or expand their business operations in Nigeria

\section{Infrastructural Dimension:}

Infrastructural components and socio-economic indicators of a country are directly linked. In effect, as the level of infrastructure advances and becomes more accessible to the citizens of that country, it will progressively lead improved quality of life. Thus, infrastructure should be perceived as an integrated system of processes and structures, rather than, as fragmented assets.

As a result of the apparent infrastructural deficit in Nigeria, particularly in terms of (electricity, roads, water, public education and affordable housing) many organizations are left with little option but to limit their investments on certain aspects of their operations. In such a complex operating environment as Nigeria, some measure of trade-offs will have to be applied in order to sustain any business on a profitable basis. Essentially, the longer it takes for these germaine issues to be effectively addressed; it becomes more convenient for multinationals to make strategic business decisions that will not unduly expose them to the associated risks of doing business in Nigeria. It is thus not unusual for such organizations to scale down operations in Nigeria in preference for more favourable neighbouring countries, downsize or even completely divest from Nigeria in extreme situations.

\section{The Terrorism Challenge}

Many years ago, it would have been out of place to suspect that Nigeria will experience a series of horrendous acts of terrorism perpetrated on a grand scale and with blatant impunity. Today, terrorist acts have become a reality of the everyday existence of an average Nigerian. Although there are other groups existing in Nigeria such as the Movement for the Emancipation of the Niger Delta (MEND) and the Movement for the Actualization of the Sovereign State of Biafra (MASSOB) who are famous for kidnapping for ransom, oil theft and pipe-line vandalization (Adeyemi, 2010); the notoriety of the Boko Haram sect is undeniable. This is apparent in the increasing trend of their criminal activities ranging from the bomb blasts, destruction of lives, properties (Jimmoh, 2011) and very recently kidnap and blackmail.

The impacts of of the activities of Boko Haram insurgents on the Nigerian business environment are indelible and multi-faceted. Alao, Atere and Alao (2012) state that the insurgence has slowed down national economic growth as it is not practicable for investors to invest in a troubled business environment. Eme and Ibietan (2013) posit that terrorism is a 'bad signal to investors', as it is progressively changing the economic structure of Nigeria. Whilst local business are shutting down and relocating to other parts of the country perceived to be less troubled, multinational corporations have relocated to relatively safer countries and 
potential multinational corporations are reviewing their interests as regards investing in Nigeria because of the terrorism challenges.

\section{Conclusion}

The critical views on globalization are seemingly politicized, making the essential issues blurred. Emphasis should be laid on what globalization entails and how it can be beneficial to all. Constant evaluation should be carried out dispassionately to determine in practical terms the achievements of towing the lane of globalization.

Multinational corporations will continue to seek new markets across borders to achieve the objective of profit maximization. The challenge for the stakeholders in the Nigerian context is to synergize and ensure the viability of the business environment for both multinational corporations and local businesses.

\section{Rreferences}

[1]. Alao, D.O., Atere, C.O., \& Alao, O. (2012). Boko Haram insurgence in Nigeria: The challenges and lessons. Singaporean Journal of Business Economics and Management Studies, 1(4), 1-15. Aninat, E. (2002). Surmounting the Challenges of Globalization, Finance \& Development, 39(1).

[2]. Anon. (2008, October 10). Zoellick: Globalization offers tremendous benefits, People's Daily China.

[3]. Anon. (2002). Anderson discovers the dark side of globalization, Strategic Direction, 18:7, 5-7.

[4]. Berger, P.L. (1997). Four Faces of Global Culture, National Interest, 23-29.

[5]. Beamish, P. W., Killing, J.P., LeCraw, D.J. \& Crockell, H. (1991). International Management: Text and Cases, in Rollinson, D., (2005), Organizational Behaviour and Analysis: An Integrated Approach, Financial Times/Prentice Hall, 666-667.

[6]. Bisley, N.(2007). Rethinking Globalization, Basingstoke: Palgrave Macmillan, 211-225.

[7]. Brawley, M.R. (2003). The Politics of Globalization, in Sparrow, P., Brewster, C., Harris, H., (2004), Globalizing Human Resource Management, London: Routledge, 15-38.

[8]. Brinkman, R.L. \& Brinkman, J.E. (2002). Corporate power and the globalization process, International Journal of Social Economics, 29(9), $730-752$.

[9]. Brooks, S.G., \& Wohlforth, W.C. (2002). From old thinking to new thinking in qualitative research, International Security, 26(4).

[10]. Bulus, H., \& Ango, N.A. (2012). Multinational Corporations: Corporate Social Responsibility Performance in Lagos State, Nigeria: A qualitative analysis, European Journal of Globalization and Development Research, 5(1).

[11]. Cadwalladr, C. (2007). Burberry Checks Out, The Observer Magazine, 36-37.

[12]. Chisholm, B. (1946) in Maddock, R. (2002), Social Globalization: Musings by Maddock.

[13]. Cook, W.N. (2006). 'Multinationals, globalization and industrial relations', in Morley, Michael J., Gunnigle, P. \& Collings, D.G., Global Industrial Relations, Oxon: Routledge.

[14]. Eaton, J. (2000). Transnational Companies, Globalization and Industrial Relations, Comparative Employment Relations, Cambridge: Polity Press.

[15]. Eme, O.I, \& Ibietan, J. (2012). The cost of Boko Haram activities in Nigeria. Arabian Journal of Business and Management Review, 2(2), 10-32.

[16]. Frynas, J.G. (2002). The limits of globalization- legal and political issues in e-commerce, Management Decision, 40:9, 871-880.

[17]. Giddens, A., (1999). The Third Way: the renewal of social democracy, Massachusets: Polity Press.

[18]. Gilpin, R. (1987). The political economy of international relations, Princeton University Press.

[19]. Hammond, C. \& Grosse, R. (2003). Rich man, Poor man: resources on globalization, Reference Services Review, 31(3), $285-295$.

[20]. Henderson, D. (1999). "The Changing International Economic Order: Rival Visions for the Coming Millennium," Melbourne Business School, 9 Sept.

[21]. Hill, C.W.L. (2005), International Business: Competing in the Global Marketplace, New York: The McGraw-Hill Companies, Inc.

[22]. Jenkins, H., Lee, E., \& Rodgers, G. (2007). The quest for a fair globalization three years on: assessing the impact of the world commission on the social dimension of Globalization, International Institute of Labour Studies, Geneva.

[23]. Jimmoh, A. (2011). 'Boko Haram not representing Islam' - Gov. Aliyu. Sunday Trust.

[24]. Khor, M. (2000). Globalization and the South: some critical issues, available at Kruger, H. (2002). Globalization in historical perspective

[25]. Leat, M. (2003). Multinationals and employee relations, Employee Relations, London: Financial Times/Prentice Hall.

[26]. Lloyd, J. (2001). The Protest Ethic: How the Anti-Globalization Movement Challenges Social Democracy, London: Demos.

[27]. Maddock, R. (2002) Social Globalization: Musings by Maddock

[28]. Mardsen, C.T. (2004). Hyperglobalized individual: the internet, globalization, freedom and terrorism, Foresight, 6(3), 128-140.

[29]. McDougall, D. (2007). Child Sweatshop shame threatens GAP's ethical image, The Observer: Special Report, 28/10/2007, 36.

[30]. Mendenhall, M.E., Punnet, B.J. \& Ricks, D. (1995). Global Management in Rollinson, D. (2005). Organizational Behaviour and Analysis: An Integrated Approach, Financial Times/Prentice Hall, 663.

[31]. Morgan, G. (1996). Images of organizations, Thousand Oaks: Sage.

[32]. Obaseki, P.J. (2000). Globalization and the Nigerian Economy, Central Bank of Nigeria Economic and Financial Review, 38(2), 1733.

[33]. Ozoigbo,B.I., \& Chukuezi,C.O. (2011). The Impact of Multinational Corporations on the Nigerian Economy, European Journal of Social Sciences, 19(3).

[34]. Parker, B. (1998). Globalization and business practice: managing across boundaries in Sparrow, P., Brewster, C. \& Harris, H. (2004). Globalizing Human Resource Management, London: Routledge, 15-38.

[35]. Perlmutter, H. (1969). The tortuous evolution of the multinational corporation, Columbus Journal of World Business, 4(1), 9-18.

[36]. Reich, R. (1994). The Work of Nations in Sparrow, P., Brewster, C. \& Harris, H. (2004). Globalizing Human Resource Management, London: Routledge, 15-38.

[37]. Rollinson, D.(2005). Organizational Behaviour and Analysis: An Integrated Approach, Financial Times/Prentice Hall, 661 -691.

[38]. Sparrow, P., Brewster, C., \& Harris, H. (2004). Globalizing Human Resource Management, London: Routledge, 15-38.

[39]. Stiglitz, J. (2002). Globalization and its discontents Penguin Books, Harmondworth.

[40]. The International Monetary Fund (2000). Globalization: Threat or Opportunity.

[41]. UNCTAD (2004). World Investment Report 2004, New York: United Nations. 
[42]. Viewpoint: (2004). Maximizing the return on HR investment: the benefits and challenges of global strategic HRM, Human Resource Management Digest, 12:3, 8-10.

[43]. Wild, A. (2003). Pressure Point, People Management, 9(14), 34-35.

[44]. Wind, Y. (1986). The myth of globalization, Journal of Consumer Marketing, 3(2), 23-26.

[45]. Wolf, W. (2004). Why Globalization Works, London: Yale University Press.

[46]. World Bank (2000). Poverty in an age of http://www.worldbank.org/economicpolicy/globalization/documents/povertyglobalization.

Globalization, available at:

[47]. Wright, R., (2000), Will Globalization make you happy? Foreign Policy. September/October, 55-64. 